\title{
Sleep History Taking and Examination
}

\author{
Himanshu Garg
}

\begin{abstract}
Sleep is the essence of productive and a healthy life. This chapter provides a comprehensive outlook for patient assessment including sleep history taking, detailed examination through general assessment as well as sleep diary. Special focus has been laid upon common and useful questionnaires which are not only inexpensive but also validated to be used in sleep apnea patients. Sleep history needs to be corroborated from the bed partner along with detailed examination from the patient. It is important to conduct the physical examination which constitutes various parameters like BMI, neck circumference, upper airway examination, etc. Efficient sleep history serves as a good predictor of sleep apnea and should not be missed before a patient undergoes polysomnography test. Usage of sleep diary has been largely underplayed in general practice, but if administered correctly it provides key information about patient's sleep hygiene and practices.

Keywords: Sleep apnea, Sleep diary, Sleep history taking, Sleep questionnaires

International Journal of Head and Neck Surgery (2019): 10.5005/jp-journals-10001-1363
\end{abstract}

\section{What is the Importance of Sleep History TAKING?}

Like in most other disease conditions a detailed sleep history taking is key in making the diagnosis. ${ }^{1}$ As far as possible the patient should be prompted to be elicit history in his own words and later leading questions can be added. ${ }^{2}$ The chief complaints can be grossly divided into nighttime complaints and daytime problems. The sleep history needs to be corroborated from the bed partners. ${ }^{3}$ Often the patient may not be aware of some of the problems with their sleep and the history is only available from the attendants. Detailed social history is very important to diagnose sleep disorders especially sleep disorders like insomnia and a number of social factors can be contributing to it and the key to addressing the disorder is to understand the social dynamics. It is also important to elicit a detailed medical history as other medical conditions can both a contributing to sleep problems and also a consequence of sleep disorders. A structured sleep history can follow the following pattern.

\section{Detailed Sleep History Questionnaire ${ }^{4}$}

\section{Sleep Timings}

- How many hours do you generally sleep? (do not include the hours you spend awake on bed)

- How many hours does it take for you to feel well rested?

- Do you take daytime naps and for how long (weekdays and weekends)?

\section{Normal Sleeping Habits}

- What time do you go to bed on a normal day?

- What time do you get out of bed on a normal day?

- What is the time required for you to fall asleep once you go to bed?

- Do you get up in middle of the night? If yes, how many times and what is it that wakes you up?

- How quickly are you able to get back to sleep?
Department of Respiratory and Sleep Medicine, W Pratiksha Hospital, Sleepcuresolutions, Gurugram, Haryana, India

Corresponding Author: Himanshu Garg, Department of Respiratory and Sleep Medicine, W Pratiksha Hospital, Sleepcuresolutions, Gurugram, Haryana, India, e-mail: drhimgarg@yahoo.com

How to cite this article: Garg H. Sleep History Taking and Examination. Int J Head Neck Surg 2019;10(1):9-17.

Source of support: Nil

Conflict of interest: None

(Address these questions separately for weekdays as well as weekends)

\section{Sleep Quality}

- Do you feel refreshed in the morning?

- How long does it take for you to feel refreshed after awakening?

- During the day, are you chronically fatigued, sleepy or tired?

\section{Snoring}

- Do you think, you snore in the night?

- Are your snores heard outside the bedroom?

- Do you think your snoring is worse while lying on back or on either side?

- Can you suggest, how many nights per weeks do you snore?

- Does it awaken the bed partner?

- Is this worse on the night you have stuffed nose or consume alcohol.

\section{Apneic Event}

- Has your bed partner noticed that you transiently stop breathing while asleep?

- Have you ever witnessed that while you sleep there is a silent period with no snoring followed by a loud snort or a body jerk which awakens you?

- Have you experienced episodes of choking or waking up in the night shortness of breath?

This history is often elicited by the bed partners.

(1) The Author(s). 2019 Open Access This article is distributed under the terms of the Creative Commons Attribution 4.0 International License (https://creativecommons. org/licenses/by-nc/4.0/), which permits unrestricted use, distribution, and non-commercial reproduction in any medium, provided you give appropriate credit to the original author(s) and the source, provide a link to the Creative Commons license, and indicate if changes were made. The Creative Commons Public Domain Dedication waiver (http://creativecommons.org/publicdomain/zero/1.0/) applies to the data made available in this article, unless otherwise stated. 


\section{Abnormal Behavior During Sleep}

- Do you have an urge to move your limbs in early part of night?

- Has anyone noticed any abnormal movements/behavior in the night?

\section{Daytime Functioning}

- Do you wake up with a headache or heaviness in head?

- Have you felt that you are mostly tired/fatigued during the day?

- Have you ever dozed of in meeting or while driving?

- What time do you get home from your work place?

- What time do you have your dinner?

\section{Personal Habits}

- Any history of alcohol consumption?

- How many drinks? per day/per week/per month

- What time of day is your last drink?

- Any history of tobacco consumption?

- If yes, how many per day and for how many years?

- If yes, what time of day is your last use?

- History of consumption of tea/coffee

- How many time and what time of the day/night

- Any consumption of hyper caffeinated drinks.

\section{Medical History}

A detailed medical history needs to be taken and specific details need to asked regarding

- Heart diseases/skipped heart beats/ heart failure/ high blood pressure

- Thyroid problems/

- Diabetes

- Stroke/epilepsy/headaches

- Asthma/emphysema/sinusitis/nasal congestion/deviated nasal septum/enlarged tonsils allergies

- Depression/anxiety/bipolar disorder.

\section{Drug History}

- All medications need to be noted with special emphasis on

- Any sedatives/antidepressants/anxiolytics.

\section{Any Established Comorbidities State/Condition}

- Cardiovascular disease

- Cerebrovascular disease

- Metabolic syndrome

- Gastroesophageal reflux

- Obesity.

\section{Occupational History}

- Does your job involve a lot of stress?

- Is your work timing out of 9 AM-5 PM? (if not everyday/ but mostly)

- Does your job demand regular flight travel to the western countries?

\section{Social History}

- General quality of life should be evaluated

- General attitude of the patient and his family/colleagues.

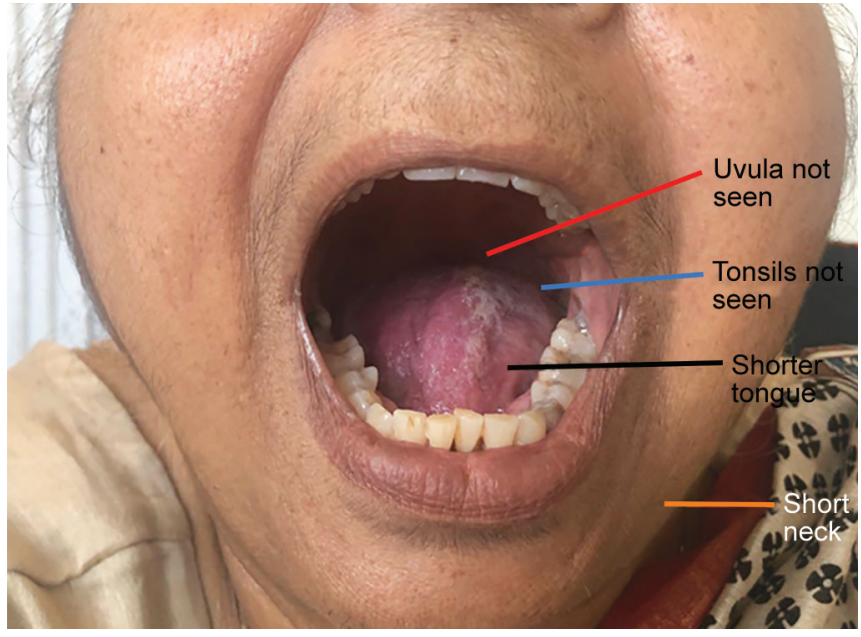

Fig. 1: Features on clinical examination of opened mouth

\section{Examination}

What can a physician examine in sleep apnea (Fig. 1)?

- Obesity ${ }^{5}$

- Body mass index (height/weight $)^{5}$

- Neck circumference ${ }^{5}$

- Enlarged tonsils ${ }^{5}$

- Elongated soft palate

- Larger tongue 5

- High-arched hard palate

- Enlarged uvula ${ }^{5}$

- Facial abnormalities (retrognathia or micrognathia) ${ }^{6}$

- Large degree of overjet

- Medical conditions: High blood pressure, metabolic disease, cardiovascular disease, stroke. ${ }^{6}$

Obesity is a major concern in obstructive sleep apnea (OSA). It is estimated that $45 \%$ obese individuals may have OSA. What simply happens in obesity is the fat deposition in the tissues surrounding the upper airways leading to smaller lumen and increased chances of collapsibility during sleep leading to sleep apnea. ${ }^{7}$

\section{Sleep Diary}

It is a record of a patient's sleep and wake patterns (Fig. 2). ${ }^{8}$ The diary is meant to capture sleep wake information over several weeks. Patients can be instructed to record the information by themselves or it can be recorded by a caregiver. It aims to measure the pattern and quality of sleep, and factors that may affect patient's sleep.

\section{General Instruction for the Patient ${ }^{9}$}

- Fill the diary every day for minimum two weeks

- Generally, fill the diary after one hour of getting up from the bed in the morning

- Be as specific as you can

- If you forget to fill the diary on a particular day, leave it blank for that day

- Make brief notes of anything unusual which has affected your sleep in the diary 


\section{SAMPLE SLEEP DIARY}

NAME:

START DATE:

COMMENTS:
AGE:

GENDER: M/F

END DATE:

\begin{tabular}{|c|c|c|c|c|c|c|c|c|}
\hline S.NO & $\begin{array}{l}\text { PLEASE ANSWER } \\
\text { THESE IN THE } \\
\text { MORNING(ROUG } \\
\text { HLY MENTION } \\
\text { THE TIME }\end{array}$ & MONDAY & TUESDAY & WEDNESDAY & THURSDAY & FRIDAY & SATURDAY & SUNDAY \\
\hline 1. & $\begin{array}{l}\text { What time did you } \\
\text { get into the bed } \\
\text { last night? }\end{array}$ & & & & & & & \\
\hline 2. & $\begin{array}{l}\text { What time did you } \\
\text { put everything off } \\
\text { and tried to sleep }\end{array}$ & & & & & & & \\
\hline 3. & $\begin{array}{l}\text { How long did it } \\
\text { take you to fall } \\
\text { asleep after that? }\end{array}$ & & & & & & & \\
\hline 4. & $\begin{array}{l}\text { What did you do } \\
\text { between getting } \\
\text { into bed and } \\
\text { falling asleep? }\end{array}$ & & & & & & & \\
\hline 5 & $\begin{array}{l}\text { Did you wake up } \\
\text { during the night? } \\
\text { How often?How } \\
\text { often were your } \\
\text { awake total? }\end{array}$ & & & & & & & \\
\hline 6. & $\begin{array}{l}\text { What time was } \\
\text { your final } \\
\text { awakening this } \\
\text { morning? }\end{array}$ & & & & & & & \\
\hline 7. & $\begin{array}{l}\text { What time did } \\
\text { you get out of } \\
\text { bed? }\end{array}$ & & & & & & & \\
\hline 8. & $\begin{array}{l}\text { Did anything } \\
\text { unusual happen } \\
\text { yesterday that } \\
\text { might have } \\
\text { affected your } \\
\text { sleep?(IIIness, } \\
\text { disturbances, } \\
\text { emotional stress } \\
\text { etc) }\end{array}$ & & & & & & & \\
\hline 9. & $\begin{array}{l}\text { What is the total } \\
\text { amount of time } \\
\text { you slept last } \\
\text { night in hours and } \\
\text { minutes?(Best } \\
\text { estimate) }\end{array}$ & & & & & & & \\
\hline 10. & $\begin{array}{l}\text { Did you take any } \\
\text { medication that } \\
\text { might have } \\
\text { affected your } \\
\text { sleep? What? } \\
\text { When? }\end{array}$ & & & & & & & \\
\hline
\end{tabular}

Fig. 2: Sleep diary 
- In the diary, day is the time when you get up and night is the time when you got to sleep

- Do not get too bothered with respect to accurate timings, give the best estimate

\section{Sleep Disordered Breathing-related Questionnaires}

Polysomnography is considered to be the gold standard in confirming the diagnosis of Obstructive Sleep Apnea. ${ }^{10}$ Yet simple inexpensive, validated questionnaires are available that can be used as a screening tool to select patients for polysomnography (the test is expensive, cumbersome and is not reimbursed by insurance). Along with the questionnaire-based screening, the stratification is based on clinical presentation, chief complaints, physical examination and comorbidities.

\section{Berlin Questionnaire}

In 1996, at the conference on sleep in primary care, the Berlin questionnaire was developed. It is a validated tool which can be used to identify individuals who are at risk for OSA (Flowchart 1). ${ }^{11}$

The questionnaire has a total of eleven questions grouped in 3 categories around snoring, feeling tired and blood pressure. Category 1 consists of a set of 5 questions regarding history of snoring and sleep apneas. Category 2 consists of 4 questions for daytime tiredness and a question around feeling drowsy while driving a motor vehicle. Category 3 consists of 2 questions with history of high blood pressure $(>140 / 90 \mathrm{~mm} \mathrm{Hg}$ ) and BMI of $>30 \mathrm{~kg} /$ $\mathrm{m}^{2}$. Categories 1 and 2 are said to be positive having $\geq 2$ positive responses in each category. Category 3 is positive with a self-report of high blood pressure and/or a BMI of $>30 \mathrm{~kg} / \mathrm{m}^{2}$.

Patients are scored as "high risk", if scores are positive for 2 or $>2$ categories. If a patient scores positive on less than two categories than they are identified as "low risk".

\section{STOP-bang Questionnaires}

Berlin questionnaire was validated for screening OSA. While, STOPbang questionnaire was developed to screen patients undergoing preoperative evaluation for obstructive sleep apnea (Fig. 3).

The STOP questionnaire is composed of four questions:

1. S denotes - Do you snore loudly? (the snore is so loud that it can easily be heard through closed doors

2. T denotes - Do you often feel Tired, fatigued, or sleepy during daytime?

3. O denotes - Has anyone Observed you stop breathing during your sleep?

4. P denotes - Do you have or are you being treated for high blood Pressure?

Few more questions were added to the STOP component. i.e. is your BMI (BMI $>35 \mathrm{~kg} / \mathrm{m}^{2}$ ), is your age ( $>50$ years), is your neck circumference (NC>40 cm), and gender (male), which was later coined as STOP-Bang questionnaire.

The answers to all questions are quantitative, meaning yes and no. For "high risk" 2 or more than 2 questions in STOP and 3 or more than 3 questions in STOP Bang have to be answered as YES.
Whereas when a patient gives his/her answer as yes to less than 2 questions in STOP questionnaire and less than 3 questions in STOP-Bang questionnaire it is denoted as "low risk"."1

\section{Epworth Sleepiness Scale}

Epworth sleepiness scale (ESS) has seen some utility in clinical practice around the globe. Many researches are now available around ESS usage in screening daytime sleepiness not only in individuals suspected to have OSA but also among motor vehicle drivers, doctors, etc. It was first developed in 1990 by Dr Johns with slight modification that was incorporated in 1997. Dr Johns developed it to assess "daytime sleepiness" in his own private practice of sleep medicine. He named the questionnaire after Epworth Hospital in Melbourne, where he also established the Epworth Sleep Centre in 1988 (Fig. 4). ${ }^{13}$

ESS is a validated questionnaire which can be easily administered by the patient himself. Subjects have to answer to 8 questions. The questions are rated as-how likely is it that they would doze/ fall asleep in 8 specific situations or activities that an individual commonly encounters in everyday life.

The scores range $0-3(0=$ would never doze, $1=$ slight chance of dozing, 2 = moderate chance of dozing, and $3=$ high chance of dozing) and the cumulative score may vary from 0 to 24 .

The total score can be inferred as follows:

- 0-10: Normal (no excessive daytime sleepiness)

- 11-12: Mild daytime sleepiness

- 13-15: Moderate daytime sleepiness

- 16-24: Severe daytime sleepiness

Practically speaking, ESS is easy to administer and inexpensive which makes it readily usable in routine clinical practice

\section{Actigraphy}

Actigraphy consists of using a portable wearable device which estimates sleep parameters and circadian rhythms. Information from actigraphy is obtained on the computer via a special software. Actigraph provides objective information about patient's sleeping habits in his own environment which can be estimated to be reasonably accurate (Fig. 5). Specifically, actigraphy is indicated in assisting the diagnosis of advanced sleep phase syndrome (ASPS), delayed sleep phase syndrome (DSPS) and shift work disorder. ${ }^{14}$

Additionally, it may be used in the evaluation of patients suspected of jet lag and non-24 hr sleep/wake syndrome (including that associated with blindness). Holistically, this tool can be used in evaluation of circadian rhythm sleep disorders, treatment progress and its outcomes and as a complimentary tool to home monitoring of sleep-disordered breathing. Actigraphy holds some limitation in evaluation of sleep -onset latency and daytime sleepiness.

It has also been listed by the International Classification of Sleep Disorder (ICSD-2) for confirming the diagnosis of sleep apnea, especially when the sleep patterns must be assessed over time and polysomnography test is not possible, or not available. It is also suggested by ICSD-2 that actigraphy may be used as an aid in assessment of habitual sleep time and circadian pattern in patients with behaviourally induced insufficient sleep syndrome and idiopathic hypersomnia with and without long sleep times. ${ }^{15}$ 
Flowchart 1: Berlin questionnaire

Patient information

Height: Weight: Age: Gender: Male/Female

\section{Please tick appropriate answer to each question}

\section{CATEGORY 1}

1. Do you snore?

$\square$ a. Yes

$\square$ b. No

$\square$ c. Don't know

If you snore

2. Your snoring is?

a. Slightly lower than breathing

b. As loud as talking

c. Louder than talking

d. Can be heard in adjacent room

3. How often do you snore?
$\square$ a. Nearly everyday
$\square$ b. 3-4 times a week
$\square$ c. 1-2 times a week
$\square$ d. 1-2 times a month
$\square$ e. Never or nearly never

4. Has your snoring ever bothered other people?
$\square$ a. Yes
$\square$ b. No
c. Don't know

5. Has anyone noticed that you quit breathing during your sleep?
$\square$ a. Nearly everyday
b. 3-4 times a week
$\square$ c. 1-2 times a month
d. Never or nearly never

\section{CATEGORY 2}

6. How often do you feel tired or fatigued after your sleep?
a. Nearly everyday

b. 3-4 times a week 
contd...

$\square$ c. 1-2 times a week

$\square$ d. 1-2 times a month

e. Never or nearly never

7. During your waking time, do you feel tired, fatigued or not up to par?

$\square$ a. Nearly everyday

$\square$ b. 3-4 times a week

c. 1-2 times a week

d. 1-2 times a month

e. Never or nearly never

8. Have you ever nodded off or fallen asleep while driving a vehicle?
a. Yes

b. No

If yes:

9. How often does this occur?
a. Nearly everyday
b. 3-4 times a week
c. 1-2 times a week
d. 1-2 times a month
e. Nearly or nearly never

\section{CATEGORY 3}

10. Do you have high blood pressure
a. Yes
b. No
c. Don't know

11. $\mathrm{BMI}=$

Categories 1 and 2 are considered positive if there are $\geq 2$ positive responses to each category.

Category is considered positive with a self-report of high blood pressure and/or a BMI of $>30 \mathrm{~kg} / \mathrm{m}^{2}$.

Patients are scored as "high risk" of having OSA if scores are positive for two or more than two categories.

Patients are scored as "low risk" of having OSA if scor es are positive for less than two categories. 
Sleep History Taking and Examination

Please answer the following question by checking YES or NO for each question

\begin{tabular}{|c|c|c|}
\hline STOP & & \\
\hline Snoring (Do you snore loudly) & Yes & No \\
\hline $\begin{array}{l}\text { Tiredness (Do you feel tired, fatigued, or sleepy } \\
\text { during the daytime?) }\end{array}$ & Yes & No \\
\hline $\begin{array}{l}\text { Observed Apnea (Has anyone observed that you } \\
\text { stop breathing, or choke or gasp during your } \\
\text { sleep?) }\end{array}$ & Yes & No \\
\hline $\begin{array}{l}\text { High Blood Pressure (Do you have or are you } \\
\text { being treated for high blood pressure? }\end{array}$ & Yes & No \\
\hline \multicolumn{3}{|l|}{ BANG } \\
\hline BMI (BMI more than $35 \mathrm{~kg} / \mathrm{m}^{2}$ ) & Yes & No \\
\hline Age (Age over 50 years) & Yes & No \\
\hline Neck (Neck circumference greater than $40 \mathrm{~cm}$ ) & Yes & No \\
\hline Gender (Male gender) & Yes & No \\
\hline
\end{tabular}

Fig. 3: STOP-bang questionnaires

NAME:

AGE:

How likely are you to doze off or fall asleep in following situations, in contrast to feeling just tired?

This refers to your usual way of life in recent times

Even if you haven't done some of these things recently try to work out how they would have affected you.

Use the following scale to choose the most appropriate number for each situation

$0=$ would never doze

$1=$ slight chance of dozing

2=moderate chance of dozing

It is important that you answer each question as best you can

\begin{tabular}{|l|l|}
\hline \multicolumn{1}{|c|}{ SITUATION } & CHANCE OF DOZING (0-3) \\
\hline Sitting and reading & \\
\hline Watching TV & \\
\hline Sitting, inactive in a public place (e.g. a theater or a meeting) & \\
\hline As a passenger in a car for an hour without a break & \\
\hline Lying down to rest in the afternoon when circumstances permit & \\
\hline Sitting and talking to someone & \\
\hline Sitting quietly after a lunch without alcohol & \\
\hline In a car, while stopped for a few minutes in the traffic & \\
\hline
\end{tabular}

Fig. 4: Epworth sleepiness scale
DATE: _/_I

GENDER: MALE/FEMALE 


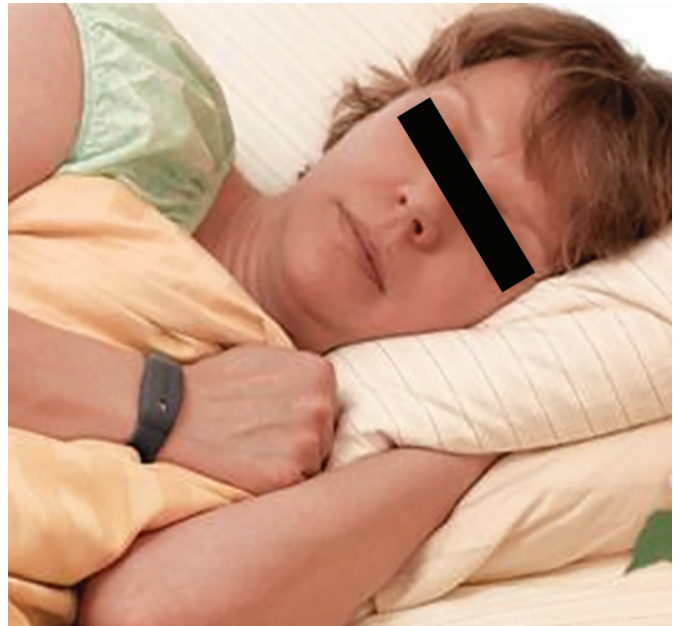

Fig. 5: Patient wearing an Actigraph while asleep

Generally, actigraphs are available as watches which are worn on the non-dominant arm. Various parameters are reflected on the Actigraph which depend on the kind of device that is procured.

\section{Case Description}

A 45-year-male visited the respiratory clinic on 10-03-2018 with complaints of heavy snoring in the night, difficulty in sleeping, disturbed sleep timings, sleeping late and waking late in the morning, sleep talking, sudden jerky movements while asleep and occasional sleepless nights. On examination, patient's BMI was 30.24 and had a shorter neck. He looked tired and sleepy. His ESS was 45. On subjective assessment, he mentioned his tea intake was 10cups across the day and the last cup was around 8 in the night. Patient did not have any relevant medical history (Fig. 6 and Table 1).

The physician recommended the patient to maintain a sleep diary and wear an actigraph on his left wrist and revisit the physician after 2 weeks.

\section{Patient's sleep diary}

\begin{tabular}{|l|l|}
\hline Name: & MR X \\
\hline Age: & 45 \\
\hline Gender: & Male \\
\hline Start date & $10-03-2018$ \\
\hline End date: & $17-03-2018$ \\
\hline
\end{tabular}

\section{Patient's Treatment}

- Weight reduction through diet and exercise

- Restricted active time in the bed (do not go to the bed until not sleepy)

- Bedroom should be used only to sleep (bedroom should not harbor television, mobile phone, laptops or any electronic device )

- Reduction in number of teas and consumption of last cup before by $6 \mathrm{pm}$ in the evening

- Use bright light to get off the bed the next morning (open the curtains)

- Strict waking up timings

- Meditation and mindfulness.

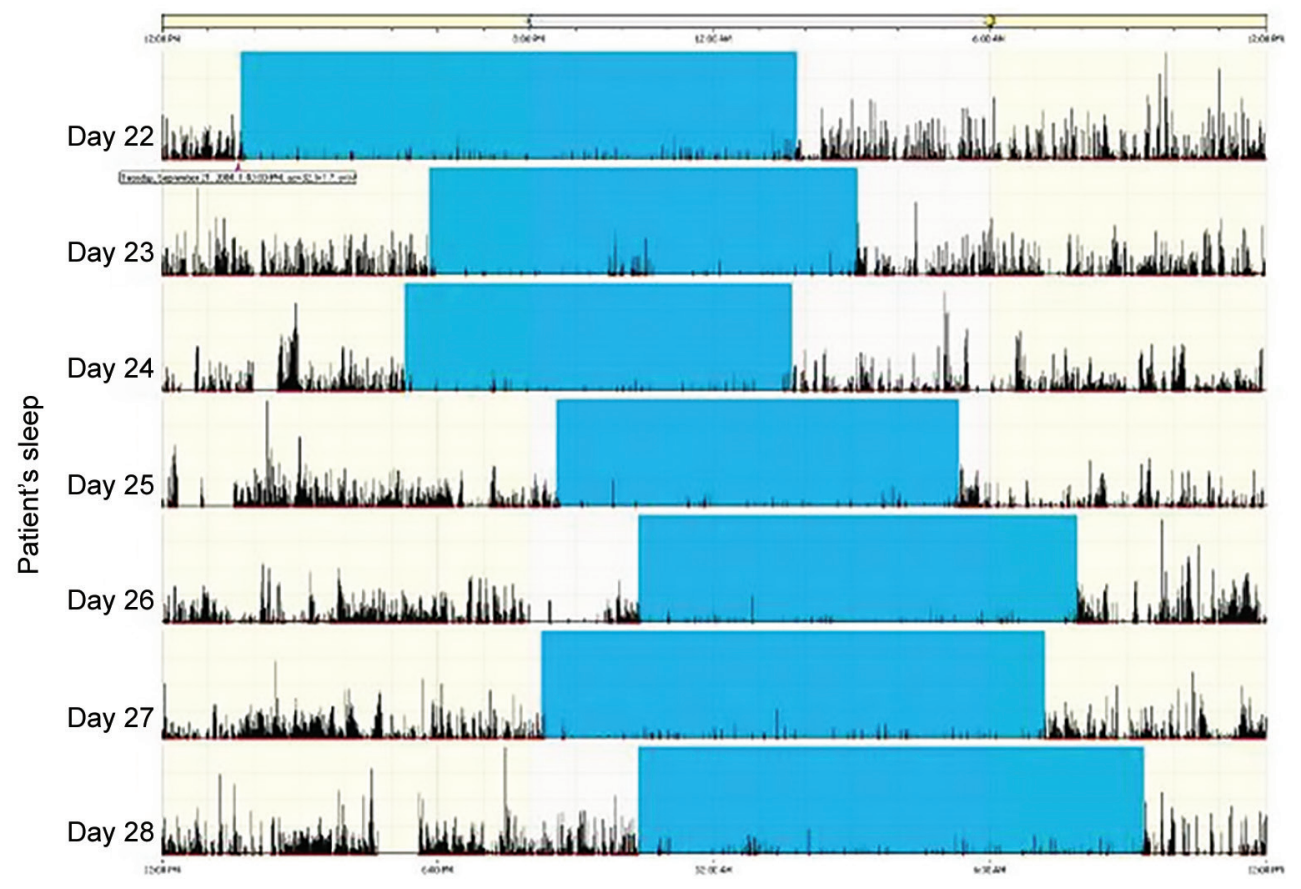

Fig. 6: Patient's actigraphy report 
Sleep History Taking and Examination

Table 1: Patient's subjective assessment

\begin{tabular}{|c|c|c|c|c|c|c|c|c|}
\hline S. No & $\begin{array}{l}\text { Please answer these in the morning } \\
\text { (roughly mention the time) }\end{array}$ & $\begin{array}{l}\text { Monday } \\
12-03-2018\end{array}$ & $\begin{array}{l}\text { Tuesday } \\
13-03-2018\end{array}$ & $\begin{array}{l}\text { Wednesday } \\
14-03-2018\end{array}$ & $\begin{array}{l}\text { Thursday } \\
15-03-2018\end{array}$ & $\begin{array}{l}\text { Friday } \\
16-03-2018\end{array}$ & $\begin{array}{l}\text { Saturday } \\
17-03-18\end{array}$ & $\begin{array}{l}\text { Sunday } \\
18-03-18\end{array}$ \\
\hline 1. & $\begin{array}{l}\text { At what time did you go to bed } \\
\text { last night? }\end{array}$ & $11 \mathrm{pm}$ & $12 \mathrm{pm}$ & $12 \mathrm{pm}$ & $11 \mathrm{pm}$ & $12: 00 \mathrm{am}$ & $1 \mathrm{am}$ & $12: 30 \mathrm{am}$ \\
\hline 2. & $\begin{array}{l}\text { What time did you put everything } \\
\text { off and tried to sleep }\end{array}$ & $11: 30 \mathrm{pm}$ & $12: 30 \mathrm{am}$ & $1 \mathrm{am}$ & $11: 30 \mathrm{pm}$ & $12: 45 \mathrm{pm}$ & 02:00 am & $1 \mathrm{am}$ \\
\hline 3. & $\begin{array}{l}\text { After how much time did you fall } \\
\text { asleep? }\end{array}$ & 1 hour & $1 / 2$ hour & 2 hours & $1 / 2$ hour & $45 \mathrm{~min}$ & 1 hour & $1 / 2$ hour \\
\hline 4. & $\begin{array}{l}\text { What did you do between getting } \\
\text { into bed and falling asleep? }\end{array}$ & $\begin{array}{l}\text { Used } \\
\text { mobile } \\
\text { phone }\end{array}$ & Used laptop & $\begin{array}{l}\text { Used } \\
\text { mobile } \\
\text { phone and } \\
\text { TV }\end{array}$ & Watched TV & Watched TV & $\begin{array}{l}\text { Did office } \\
\text { work on } \\
\text { laptop }\end{array}$ & Watched TV \\
\hline 5 & $\begin{array}{l}\text { Did you wake up in the middle } \\
\text { of night? For how much time? } \\
\text { For how long were you awake in } \\
\text { total? }\end{array}$ & $\begin{array}{l}\text { Yes, } 2 \text { times } \\
3 \text { hours }\end{array}$ & $\begin{array}{l}\text { Yes, } 2 \text { times } \\
4 \text { hours }\end{array}$ & $\begin{array}{l}\text { Yes, } 2 \text { times } \\
2 \text { hours }\end{array}$ & $\begin{array}{l}\text { Yes, } 3 \text { times, } \\
2 \text { hours }\end{array}$ & $\begin{array}{l}\text { Yes, } 1 \text { time, } \\
1 / 2 \text { hour }\end{array}$ & Yes, 1 hour & Yes, 3 hours \\
\hline 6. & $\begin{array}{l}\text { What time was your final awaken- } \\
\text { ing this morning? }\end{array}$ & $9 \mathrm{am}$ & $8 \mathrm{am}$ & $8 \mathrm{am}$ & $9 \mathrm{am}$ & $8 \mathrm{am}$ & $10 \mathrm{am}$ & $10 \mathrm{am}$ \\
\hline 7. & $\begin{array}{l}\text { What time did you get out of } \\
\text { bed? }\end{array}$ & $10 \mathrm{am}$ & $8: 30 \mathrm{am}$ & $8: 30 \mathrm{am}$ & $9: 30 \mathrm{am}$ & $8: 30 \mathrm{am}$ & 10:15am & $10: 15 \mathrm{am}$ \\
\hline 8. & $\begin{array}{l}\text { Did anything unusual happen } \\
\text { yesterday that might have af- } \\
\text { fected your sleep? (IIlness, distur- } \\
\text { bances, emotional stress etc) }\end{array}$ & No & No & No & No & No & No & No \\
\hline 9. & $\begin{array}{l}\text { What is the total amount of time } \\
\text { you slept last night in hours and } \\
\text { minutes? (best estimate) }\end{array}$ & $\begin{array}{l}6 \text { hours } \\
30 \text { min }\end{array}$ & $\begin{array}{l}3 \text { hours } \\
30 \text { min }\end{array}$ & 3 hours & 6 hours & 6 hours & 7 hours & $\begin{array}{l}5 \text { hours } \\
30 \text { min }\end{array}$ \\
\hline 10. & $\begin{array}{l}\text { Did you take any medication that } \\
\text { might have affected your sleep? } \\
\text { What? When? }\end{array}$ & No & No & No & No & No & No & No \\
\hline
\end{tabular}

\section{References}

1. G Stores. Clinical diagnosis and misdiagnosis of sleep disorders. J Neurol Neurosurg Psychiatry. 2007 Dec; 78(12):1293-1297.

2. Walker HK, Hall WD, et al. Clinical Methods: The History, Physical, and Laboratory Examinations. 3rd edition;1990.

3. Clete Kushida. Sleep Medicine Clinics, Evaluation of Sleep Complaints, An Issue of Sleep Medicine Clinics, e-Book. 2014 Dec;9(4).

4. Harrison G Bloom, Imran Ahmed, et al. Evidence-Based Recommendations for the Assessment and Management of Sleep Disorders in Older Persons. J Am Geriatr Soc. 2009 May; 57(5):761-789.

5. Schellenberg JB, Maislin G, et al. Physical findings and the risk for obstructive sleep apnea. The importance of oropharyngeal structures. Am J Respir Crit Care Med. 2000 Aug;162(2 Pt 1):740-748.

6. Pushkar Mehra, Larry M. Wolford. Surgical management of obstructive sleep apnea. Proc (Bayl Univ Med Cent). 2000 Oct;13(4): 338-342.

7. Abel Romero-Corral, Sean M Caples, et al. Interactions between Obesity and Obstructive Sleep Apnea. Implications for Treatment. Chest. 2010 Mar;137(3):711-719.

8. Colleen E Carney, Daniel J Buysse, et al. The Consensus Sleep Diary: Standardizing Prospective Sleep Self-Monitoring. Sleep. 2012 Feb 1; 35(2): 287-302.
9. Colleen E Carney, Daniel J Buysse, et al. The Consensus Sleep Diary: Standardizing Prospective Sleep Self-Monitoring. Sleep. 2012 Feb 1; 35(2):287-302.

10. Viral Doshi, Reuben Walia, et al. STOP-BANG questionnaire as a screening tool for diagnosis of obstructive sleep apnea by unattended portable monitoring sleep study. Springerplus. 2015; 4: 795.

11. Use of the Berlin Questionnaire to screen at-risk patients for obstructive sleep apnea.B-ENT 2014 April;10(1):21-25.

12. I Iman HassanEl-Sayed. Comparison of four sleep questionnaires for screening obstructive sleep apnea. Egyptian Journal of Chest Diseases and Tuberculosis. 2012 Oct;61(4):433-441.

13. Epworth Sleepiness Scale (ESS) http://epworthsleepinessscale.com/ about-the-ess/

14. Martin JL, Hakim AD. Wrist actigraphyChest. 2011 Jun;139(6):1514-1527.

15. Timothy Morgenthaler, Cathy Alessi, et al.Practice Parameters for the Use of Actigraphy in the Assessment of Sleep and Sleep Disorders: An Update for 2007 Standards of Practice Committee. American Academy of Sleep Medicine. 